\title{
Freeze Dried Acerola (Malpighia emarginata) Pulp and Pomace: Physicochemical Attributes, Phytochemical Content and Stability during Storage
}

\author{
Francisca Pereira De Moraes, Aline Cardoso Gonçalves, Thaís Bezerra Veríssimo \\ Miguel, Kátia Cristina Borges \\ Laboratory of Food Bioactive Compounds \\ Chemical Engineering Department \\ Federal University of Rio Grande do Norte \\ Campus Lagoa Nova, Natal, RN 59075-180, Brazil \\ Roberta T. P. Correia (Corresponding author) \\ Laboratory of Food Bioactive Compounds \\ Chemical Engineering Department \\ Federal University of Rio Grande do Norte \\ Campus Lagoa Nova, Natal, RN 59075-180, Brazil
}

Tel: 55-(84)-32-152-285; Fax: 55-(84)-32-153-700Ｅmail: roberta@eq.ufrn.br

Received: September 1, 2017 Accepted: September 17, 2017 Published: October 17, 2017

doi:10.5296/jfi.v1i1.11795 URL: http://dx.doi.org/10.5296/jfi.v1i1.11795

\begin{abstract}
In this study, acerola pulp and acerola pomace were freeze dried with and without gum Arabic (GA) and analyzed in regard to their physicochemical attributes, bioactive content, and phytochemical stability (total phenolic content, ascorbic acid, total monomeric anthocyanins and antioxidant activity), during storage at $4{ }^{\circ} \mathrm{C}$ and $25{ }^{\circ} \mathrm{C}$. The freeze dried products were highly porous and had low water activity $(0.273$ to 0.300$)$. Freeze dried acerola pulp with GA were the most soluble samples (64.1\% to $73.7 \%$ ). The addition of GA to freeze dried acerola pomace increased samples hygroscopicity from $4.5 \%$ to $11.1 \%$. High ascorbic acid retention in freeze dried acerola pulp was observed for all samples $\left(65.2 \%\right.$ at $25{ }^{\circ} \mathrm{C}$ and $88.9 \%$ at $4{ }^{\circ} \mathrm{C}$ ). It was observed that freeze dried acerola pomace showed increased
\end{abstract}


antioxidant activity during storage $\left(101.9 \%\right.$ at $4{ }^{\circ} \mathrm{C}$ and $135.9 \%$ at $\left.25{ }^{\circ} \mathrm{C}\right)$. Our results demonstrate the potential of freeze dried acerola pulp and pomace as novel food ingredients with concentrated phytochemical content and desirable physicochemical attributes.

Keywords: bioactive compounds, antioxidant, fruit products, drying

\section{Introduction}

Acerola (Malpighia emarginata) is a berry-like fruit native to the Americas, but it is currently cultivated in several other continents (Assis, Fernandes, Martins, \& Oliveira, 2008). Acerola once got the attention of researchers and the public in general due to its high ascorbic acid concentration, but other important bioactive compounds such as phenolic compounds and natural pigments have also been detected in this fruit (Nóbrega, Oliveira, Genovese, \& Correia, 2015; Paz et al., 2015; Silva, Duarte, \& Barrozo, 2016).

The main industrial use of acerola fruits is the production of acerola pulp, which represents $70-80 \%$ of total fruit weight (Furlaneto \& Nasser, 2015). The resulting pomace $(20-30 \%)$ is frequently discarded or used for animal feed, despite several studies showing high concentration of residual bioactive compounds in acerola pomace (Nóbrega et al., 2015; Silva et al., 2016). Since it is suited to the tropical climate, acerola is commercially cultivated in Brazil (Jaeschke, Marczak, \& Mercali, 2016), where it occupies around 10000 hectares (Furlaneto \& Nasser, 2015). There is a great market for bioactive-rich fruits derivatives in the Northern hemisphere, and acerola is one of the crops that have become an important source of income in the agricultural business of several countries. Unfortunately, acerola fruits rapidly decay, and therefore, technological processes should be applied to extend its shelf life and marketability, to generate versatile products that are easier to store and distribute, and to minimize harvest wastes. Drying has been successfully applied to fruits and it has been proved to be an efficient way to obtain fruit derivatives with concentrated naturally occurring phytochemicals, and desirable attributes (Karam, Petit, Zimmer, Baudelaire Djantou, \& Scher, 2016; Sampaio et al., 2017).

Freeze drying is a popular drying technique suitable to thermal-sensitive products. It is based on the phenomena of sublimation and high quality final products with preserved phytochemicals, flavor and aroma are generally obtained (Harnkarnsujarit, Kawai, Watanabe, \& Suzuki, 2016). As opposed to spray drying, drying carriers are not necessarily used for freeze drying, but studies have shown several advantages in doing so. For example, high encapsulation efficiency (>90\%) was observed when drying green tea polyphenols (Pasrija, Ezhilarasi, Indrani, \& Anandharamakrishnan, 2015) and Garcinia fruits (Ezhilarasi, Indrani, Jena, \& Anandharamakrishnan, 2013) and enhanced preservation of bioactive compounds was observed for grapefruit when wall materials were added during freeze drying (Agudelo, Barros, Santos-buelga, Martínez-navarrete, \& Ferreira, 2017). In fact, the effectiveness of phytochemicals depends on their stability during food processing and storage and their preservation is critical for the success of any technological process (Nora et al., 2014).

Presently, to the best of our knowledge, there is no information about the characteristics of freeze dried acerola pulp and pomace using a drying carrier. Considering the commercial 
importance of acerola and its outstanding phytochemical content, the objective of this study was to investigate the physicochemical and bioactive properties of freeze dried acerola pulp and pomace with and without gum Arabic after processing and along 120 days of storage at $4{ }^{\circ} \mathrm{C}$ and $25^{\circ} \mathrm{C}$. To this purpose, selected biologically active compounds such as ascorbic acid, anthocyanins and phenolic compounds were evaluated, as well as the structure and physicochemical attributes of final products. This study provides a deeper knowledge about the changes occurred during freeze drying of acerola, and it might have broad implications on the development and elaboration of dried fruit-based functional products.

\section{Material and methods}

\subsection{Material}

Several batches of fruits consisting of red and purple acerola were purchased from the local market (Natal, RN, Brazil). The fruits were sanitized and homogenized in order to constitute a single batch that was used in all experiments. They were further processed into fruit pulp using a depulping machine (model Compacta, Itametal, Brazil). The acerola pomace was obtained as the by-product of acerola depulping and consisted of peels, residual pulp and seeds after pulp extraction. Both the acerola pulp and acerola pomace were used for freeze drying experiments after frozen storage $\left(-18^{\circ} \mathrm{C}\right)$ for no more than two weeks.

\subsection{Freeze Drying Process}

The freeze drying process (freeze drier model L101, Liobras, Brazil) was performed under the following operational parameters: constant speed of $1 \mathrm{~mm} / \mathrm{h}$, vacuum of $0.5 \mathrm{mmHg}$ and final pressure of $0.05 \mathrm{mmHg}$. Samples were freeze dried for 48 hours at $-40{ }^{\circ} \mathrm{C}$. Four experimental groups were prepared: PU (acerola pulp), PUG (acerola pulp with gum Arabic, PO (acerola pomace) and POG (acerola pomace with gum Arabic). The groups with gum Arabic (PUG and POG) were prepared by mixing gum Arabic $(3 \% \mathrm{w} / \mathrm{w})$ to pulp or pomace for $3 \mathrm{~min}$ using a mechanical mixer until complete dissolution. Due to its natural heterogeneity, freeze dried pomace samples were ground (mill TE-631/2, Tecnal, Brazil) and standardized using 24-mesh sieves.

\subsection{Water Activity, Hygroscopicity and Solubility}

Freeze dried samples were analyzed for water activity (Aqualab Decagon, 4 TE, EUA). Hygroscopicity was expressed as water absorbed by freeze dried samples $(0.5 \mathrm{~g})$ stored in Petri plates for 7 days in a dissecator containing $\mathrm{NaCl}$ saturated solution ( $\mathrm{RU}$ 75.3\%) according to Souza, Thomazini, Balieiro, Fávaro-Trindade (2015). Samples solubility (Cano-Chauca, Stringheta, Ramos, Cal-Vidal, 2005) was evaluated by mixing $1 \mathrm{~g}$ sample to $100 \mathrm{~mL}$ water and stirring for $5 \mathrm{~min}$ at $3000 \mathrm{rpm}$. Aliquots of the supernatant $(25 \mathrm{~mL})$ were transferred to Petri plates and oven dried for $5 \mathrm{~h}$ at $105^{\circ} \mathrm{C}$. Solubility (\%) was calculated as the difference between final and initial weight.

\subsection{Scanning Electron Microscopy (SEM) and X-ray Diffraction}

The surface structure of freeze dried samples was observed through a scanning electron microscope (TM3 000, Hitachi High Technologies, USA) working at an accelerating voltage 
of $5 \mathrm{kV}$ and $15 \mathrm{kV}$. The overall structure and crystallinity was evaluated with a powder X-ray diffraction meter (model XRD 7000 , Shimadzu, Japan). Scans were performed in the $2 \theta$ range of $5^{\circ}-120^{\circ}$ with an increase of $1 \%$ min and $0.02^{\circ}$-intervals (Cano-Chauca et al., 2005).

\subsection{Water, milk and Oil-Holding Capacities}

The water-holding capacity (WHC) and milk-holding capacity (DMHC: defatted milk; WMHC: whole milk) of freeze dried samples were evaluated according to López-Marcos, Bailina, Viuda-Martos, Pérez-Alvarez, Fernández-López (2015). Briefly, $10 \mathrm{~mL}$ of water or milk were added to a centrifuge tube containing $300 \mathrm{mg}$ of sample. The tubes with water were stored at $25{ }^{\circ} \mathrm{C}$ (RU 62\%) and tubes with milk at $4{ }^{\circ} \mathrm{C}(\mathrm{RU} 10 \%)$ for $18 \mathrm{~h}$. After this, tubes were centrifuged for $20 \mathrm{~min}$ at $25^{\circ} \mathrm{C}$ and $3000 \mathrm{rpm}$ (Universal 320R, Hettich, Brazil) and the supernatant was discarded. The precipitated was weighed and results were expressed as $g$ of water or milk held per $1 \mathrm{~g}$ of freeze dried sample. Similar procedure was used for oil-holding capacity, but $160 \mathrm{mg}$ of sample and $5 \mathrm{~g}$ of sunflower oil were used instead. Results were expressed as $\mathrm{g}$ of oil held per $1 \mathrm{~g}$ of freeze dried sample.

\subsection{Color Analyses}

CIELAB parameters $\left(\mathrm{L}^{*}, \mathrm{a}^{*}\right.$ and $\mathrm{b}^{*}$ ) were evaluated using a colorimeter (CR-400, Konica Minolta, Japan) where $\mathrm{L}^{*}$ indicates brightness/darkness (0: black and 100: white), a* relates to green $\left(-a^{*}\right) /$ red $\left(+a^{*}\right)$ coordinates and $b^{*}$ relates to blue $\left(-b^{*}\right)$ yellow $\left(+b^{*}\right)$ coordinates.

\subsection{Phytochemical Content}

\subsubsection{Preparation of Extracts}

Water extracts were prepared following the procedure previously shown by Azevêdo, Fujita, Oliveira, Genovese, Correia (2014). Samples $(0.2 \mathrm{~g})$ were added to $100 \mathrm{~mL}$ and mixed under constant stirring for $1 \mathrm{~h}$. The obtained solution was filtered with Whatman paper filter $\mathrm{n}^{\circ} 1$ and centrifuged ( $3600 \mathrm{rpm}, 10 \mathrm{~min}, 5^{\circ} \mathrm{C}$ ) and the final extract was used for total phenolic content, anthocyanins and antioxidant activity analyses, as described further.

\subsubsection{Total Phenolic Content (TPC)}

It was determined according to Fujita, Borges, Correia, Franco, Genovese (2013) using the Folin-Ciocalteau reagent $1 \mathrm{~N}$. The samples absorbance were measured at wavelength $750 \mathrm{~nm}$ and a calibration curve was built using gallic acid concentrations ranging from $10 \mu \mathrm{g} / \mathrm{mL}$ to $200 \mu \mathrm{g} / \mathrm{mL}$. Results were expressed as gallic acid equivalent (GAE) per $100 \mathrm{~g}$ of freeze dried sample of dry weight (mg GAE eq/100 g DW).

\subsubsection{Total Monomeric Anthocyanins (ANC)}

The $\mathrm{pH}$ differential method was conducted according to Giusti \& Wrolstad (2005). Results were calculated using the absorbance of samples at $510 \mathrm{~nm}\left(\mathrm{~A}_{510}\right)$ and $700 \mathrm{~nm}\left(\mathrm{~A}_{700}\right)$, the sample dilution factor (DF), molecular weight (MW) $449.2 \mathrm{~g} / \mathrm{mol}$ and molar absorptivity $(\varepsilon)$ 26900 corresponding to cyanidin-3-glucoside as shown in Equation 1. The values were expressed in $\mathrm{mg} / 100 \mathrm{~g} \mathrm{DW}$. 


\section{MInstitute ${ }^{\text {Macrothink }}$}

$\operatorname{ANC}(\mathrm{mg} / \mathrm{g})=\left[\left(\mathrm{A}_{510}-\mathrm{A}_{700}\right)\right] \mathrm{pH}_{1}-\left[\left(\mathrm{A}_{510}-\mathrm{A}_{700}\right)\right] \mathrm{pH}_{4,5} \times\left(\mathrm{MW} \times \mathrm{DF} \times 1000 \times \varepsilon^{-1}\right)$

\subsubsection{2,2 diphenyl-1-picrylhydrazyl (DPPH) Assay for Antioxidant Activity}

It was evaluated following the procedure of Duarte-Almeida, Santos, Genovese, Lajolo, (2006) using $200 \mu \mathrm{L}$ of DPPH solution ( $40 \mathrm{mg} / \mathrm{mL}$ with $0.6-0.7$ of absorbance at $517 \mathrm{~nm}$ ) and $40 \mu \mathrm{L}$ of sample extract in 96-well microplates (TPP, Trasadingen, Switzerland). Absorbance readings $(517 \mathrm{~nm})$ were made in a microplate reader (Thermoplate Reader, Bio-Rad Laboratories, Hercules, USA) after letting samples for $25 \mathrm{~min}$ in the dark. The calibration curve was built by using methanolic TROLOX (6-hydroxy-2,5,7,8-tetramethylchroman-2-carboxylic acid; Sigma-Aldrich) solutions. Results were expressed as Trolox equivalents (TE) per gram of dry weight sample ( $\mu \mathrm{mol} \mathrm{TE} / \mathrm{g} \mathrm{DW})$.

\subsubsection{Ascorbic Acid (AA)}

The ascorbic content was evaluated using a modified AOAC method $(967.21,1990)$ using the 2,6-di-chlorophenol-indophenol methodology according to Oliveira, Godoy, Prado (2010). The extraction of ascorbic acid consisted of adding freeze dried samples $(0.5 \mathrm{~g})$ to $50 \mathrm{~mL}$ of 1:10 (w/v) metaphosphoric acid solution. The mixture was homogenized, filtered (Whatman paper filter $\mathrm{n}^{\circ} 1$ ), and centrifuged ( $3000 \mathrm{rpm}, 5 \mathrm{~min}, 5^{\circ} \mathrm{C}$ ). Samples were protected from light and results were expressed as $\mathrm{mg} \mathrm{AA} / 100 \mathrm{~g}$ DW.

2.8 Storage Stability of Ascorbic Acid, Total Phenolic Content, Anthocyanins and Antioxidant Activity at $4{ }^{\circ} \mathrm{C}$ and $25^{\circ} \mathrm{C}$

Freeze dried acerola samples $(5 \mathrm{~g})$ in amber glass recipients were divided into two groups and stored at $4{ }^{\circ} \mathrm{C}(\mathrm{RU} 10 \%)$ and $25{ }^{\circ} \mathrm{C}(\mathrm{RU} 62 \%)$. Samples were periodically removed from storage to be analyzed (TPC, ANC, AA, DPPH) after 0, 7, 15, 30, 60, 90 and 120 days.

\subsection{Statistical Analyses}

All samples were analyzed at least in triplicate and results were shown as means \pm standard deviation (SD). Data was subjected to analysis of variance $(p \leq 0.05)$ using Statistica ${ }^{\circledR} 7.0$ software. In the case of statistical significance, the Tukey test $(p \leq 0.05)$ was used to evaluate means.

\section{Results and Discussion}

\subsection{Water Activity, Hygroscopicity and Solubility}

The water activity and hygroscopicity are essential parameters for powder stability and storage, while solubility influences powder applications and its reconstitution. The water activity (Aw) of freeze dried acerola samples ranged between 0.273 and 0.301 (Table 1). This is similar to Nóbrega et al. (2015) when analyzing oven dried acerola pomace (0.204 to 0.405), but higher than spouted bed dried acerola juice ( 0.17 to 0.18 ; Araújo et al., 2015). Most of the deterioration reactions happen in water activity higher than 0.65 , therefore freeze dried acerola pulp and pomace are microbiologically stable (Soquetta et al., 2016). 
Table 1. Water activity (Aw), hygroscopicity and solubility of freeze dried acerola pulp (PU, PUG) and pomace (PO, POG) with and without gum Arabic.

\begin{tabular}{llll}
\hline & $\mathrm{A}_{\mathrm{w}}$ & Hygroscopicity (\%) & Solubility (\%) \\
\hline PU & $0.301 \pm 0.004^{\mathrm{a}}$ & $18.2 \pm 0.1^{\mathrm{a}}$ & $64.1 \pm 2.6^{\mathrm{b}}$ \\
PUG & $0.297 \pm 0.001^{\mathrm{a}}$ & $12.2 \pm 0.7^{\mathrm{b}}$ & $73.7 \pm 2.0^{\mathrm{a}}$ \\
PO & $0.288 \pm 0.006^{\mathrm{a}}$ & $4.5 \pm 0.4^{\mathrm{d}}$ & $21.5 \pm 1.6^{\mathrm{c}}$ \\
POG & $0.273 \pm 0.004^{\mathrm{b}}$ & $11.1 \pm 0.7^{\mathrm{c}}$ & $28.2 \pm 0.5^{\mathrm{c}}$ \\
\hline
\end{tabular}

Results are presented as means \pm standard deviation. Results in the same column followed by different letters $(a, b, c, d)$ are significantly different by Tukey test $(p<0.05)$. Sample identification: PU: freeze dried acerola pulp; PUG: freeze dried acerola pulp with $3 \%(\mathrm{w} / \mathrm{v})$ gum Arabic; PO: freeze dried acerola pomace; POG: freeze dried acerola pomace with $3 \%$ $(w / v)$ gum Arabic.

Samples were classified in three groups according to their hygroscopicity (GEA Niro, 2017): non-hygroscopic (PO - below $10 \%$ ), slightly hygroscopic (PUG and POG - 10.1 - 15\%) and hygroscopic (PU - 15.1 - $20 \%$ ). Interestingly, the addition of gum Arabic impacted the hygroscopicity of samples in different ways: while it decreased the hygroscopicity of acerola pulp, less hygroscopic pomace samples were obtained when gum Arabic was added $(\mathrm{p}<0.05$, Table 1). In fact, acerola pulp is naturally highly hygroscopic due to the abundant presence of sugars and acids of low molecular weight that strongly interact with water molecules, mainly in the amorphous state (Figure 2, Jaya \& Das, 2004; Tonon et al., 2009). For acerola pulp, the presence of gum Arabic affected the water interaction between molecules and a significant decrease of hygroscopicity in dried acerola pulp was observed $(p<0.05)$. On the other hand, acerola pomace consists mainly of non-hygroscopic, insoluble material, such as peels and seeds. Our hypothesis is that gum Arabic increased the concentration of polysaccharides (arabinose, galactose, glucose and others) of dried acerola pomace, which in turn increased its hygroscopicity (Nie et al., 2013).

The freeze dried acerola pulp is more soluble $(\mathrm{p}<0.05)$ when compared to freeze dried acerola pomace (Table 1). In fact, this is explained by higher concentration of soluble compounds, such as sugars and soluble fiber in acerola pulp (Aydin \& Gocmen, 2015). Moreover, solubility was greater in freeze dried samples with gum Arabic, when compared to samples without the carrier agent. The presence of gum Arabic increases the solubility of freeze dried samples due to its high water solubility (Tonon, Brabet, \& Hubinger, 2010).

\subsection{Scanning Electron Microscopy (SEM) and X-ray Diffraction}

The surface microstructure of freeze dried acerola samples is shown in Figure 1. All samples presented irregularly shaped particles with various sizes. The particles had the aspect of broken glass, similarly to what Kuck \& Noreña (2016) observed for freeze dried grape skin. This microstructure is quite different when compared to spray dried particles, which commonly exhibit spherical structures without fissures or cracks. In fact, the sublimation of water results in a rigid and porous structure with no shrinkage, which is characteristic of 


\section{Macrothink}

freeze dried samples (Conceição, Fernandes, \& Resende, 2016).

Pomace samples (PO and POG, Figures 1C and 1D) presented a more granular aspect due to the additional grinding step applied to dried pomace. Smaller size particles were observed and the higher hygroscopicity of POG samples (Table 1) explains the greater agglomeration shown in Figure 1D.
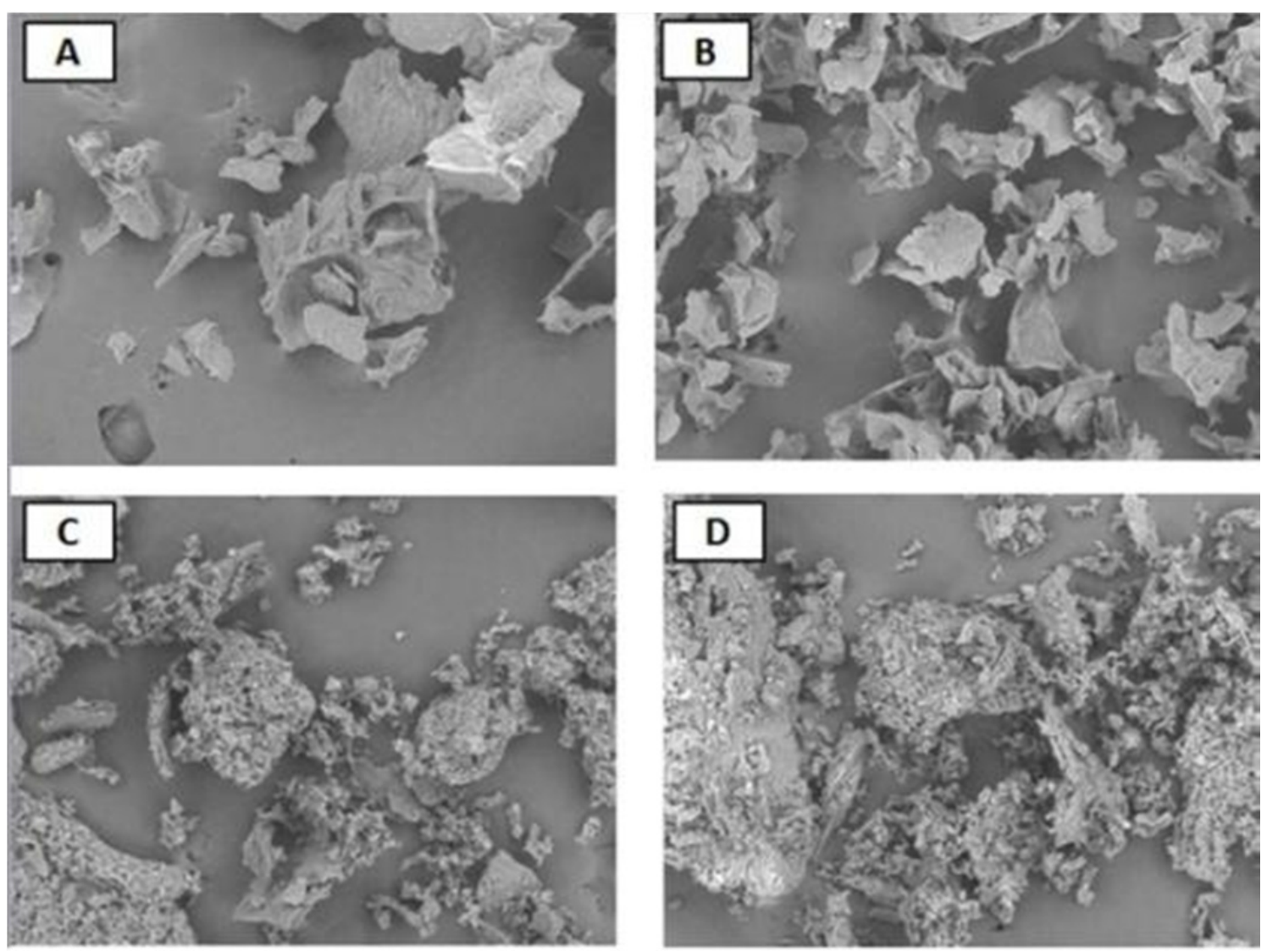

Figure 1. Micrographs (100x) of freeze dried acerola pulp and pomace with and without gum Arabic (GA). Sample identification: A: PU, freeze dried acerola pulp; B: PUG, freeze dried acerola pulp with $3 \%(\mathrm{w} / \mathrm{v})$ gum Arabic; $\mathrm{C}$ : PO, freeze dried acerola pomace; D: POG, freeze dried acerola pomace with $3 \%(\mathrm{w} / \mathrm{v})$ gum Arabic

The analysis of diffractograms allows the identification of amorphous and crystalline materials. While diffuse and large peaks are typical of disordered molecules in the amorphous state, sharp and defined peaks are characteristic of highly ordered crystalline materials (Cano-Chauca et al., 2005). Freeze dried acerola samples exhibited both amorphous and crystalline materials, detectable by broader peaks with considerable noise and semi-defined peaks (Figure 2) which are characteristic of the presence of sugars and gum Arabic (Risch \& Reineccius, 1993). Similar findings were observed for spray dried mango juice particles (Cano-Chauca et al., 2005). However, PO samples (Figure 2C) presented diffractograms with 


\section{Macrothink Institute ${ }^{T M}$}

a higher number of well-defined peaks when compared to other samples, which indicate changes in the microstructure, from a disordered state (amorphous) into more ordered molecules (crystalline). The amorphous state is more desirable for fruit powders, since it presents higher viscosity associated to lower molecular mobility, that inhibits chemical and biochemical reactions (Araujo-Díaz, Leyva-Porras, Aguirre-Manuelos, Álvarez-Salas, \& Saavedra-Leos, 2017).
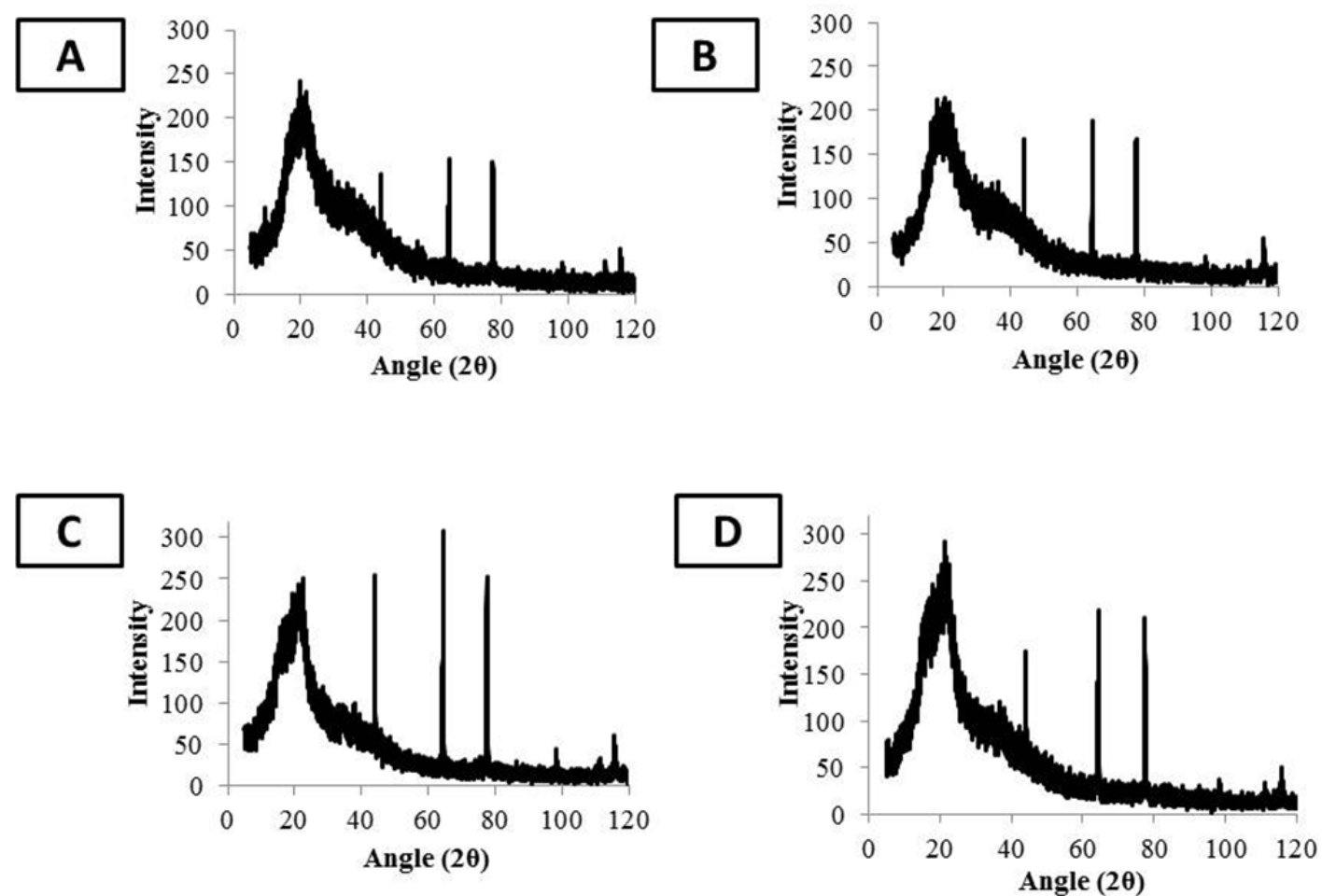

Figure 2. Diffractograms of freeze dried acerola pulp and pomace with and without gum Arabic (GA). Sample identification: A: PU, freeze dried acerola pulp; B: PUG, freeze dried acerola pulp with 3\% (w/v) gum Arabic; C: PO, freeze dried acerola pomace; D: POG, freeze dried acerola pomace with $3 \%(\mathrm{w} / \mathrm{v})$ gum Arabic

\subsection{Water, Milk and Oil-Holding Capacities}

These technological parameters are important to understand the use of freeze dried acerola as food ingredients and bring some insight about their potential incorporation in other food matrices. PU samples presented the highest water-holding capacity $(15.86 \mathrm{~g} / \mathrm{g})$ followed by PO, POG and PUG, in this order. According to Guillon \& Champ (2000), WHC is influenced by pore size distribution of samples. Higher WHC was observed here for freeze dried acerola samples (Table 2), when compared to different fiber-rich pomaces such as Citrus lemon, Citrus paradisi and Punica granatum (3.76 to 7.96 g/g, López-Marcos et al., 2015).

The oil-holding capacity of samples with gum Arabic (PUG and POG) was lower $(\mathrm{p}<0.05)$ when compared to samples without it (PU and PO). The OHC of powdered foods is relevant 


\section{Al Macrothink}

for several industry applications such as extrusion (Gurak, De Bona, Tessaro, \& Marczak, 2014). Similarly to WHC, the OHC of acerola samples was also higher when compared to citrus agroindustrial pomaces (1.69 to $3.60 \mathrm{~g} / \mathrm{g}$ ) as shown by López-Marcos et al. (2015). Overall, pomace samples presented lower holding capacity in hydrophilic solvents such as water and milk (Table 2), which might be related to higher concentration of insoluble fiber in acerola pomace when compared to acerola pulp (López-Marcos et al., 2015).

Table 2. Water-holding capacity (WHC), oil-holding capacity (OHC), defatted milk-holding capacity (DMHC) and whole milk-holding capacity (WMHC) of freeze dried acerola pulp (PU, PUG) and pomace (PO, POG) with and without gum Arabic.

\begin{tabular}{lllll}
\hline & WHC $(\mathrm{g} / \mathrm{g})$ & OHC $(\mathrm{g} / \mathrm{g})$ & DMHC $(\mathrm{g} / \mathrm{g})$ & WMHC $(\mathrm{g} / \mathrm{g})$ \\
\hline PU & $15.86 \pm 0.33^{\mathrm{a}}$ & $6.81 \pm 0.31^{\mathrm{ab}}$ & $12.06 \pm 0.06^{\mathrm{a}}$ & $15.96 \pm 0.74^{\mathrm{a}}$ \\
PUG & $6.62 \pm 0.15^{\mathrm{d}}$ & $4.65 \pm 0.16^{\mathrm{c}}$ & $7.15 \pm 0.30^{\mathrm{c}}$ & $8.43 \pm 0.14^{\mathrm{b}}$ \\
PO & $10.61 \pm 0.17^{\mathrm{b}}$ & $7.11 \pm 0.12^{\mathrm{a}}$ & $7.83 \pm 0.11^{\mathrm{b}}$ & $7.89 \pm 0.07^{\mathrm{bc}}$ \\
POG & $7.90 \pm 0.28^{\mathrm{c}}$ & $6.49 \pm 0.27^{\mathrm{b}}$ & $6.76 \pm 0.14^{\mathrm{c}}$ & $7.42 \pm 0.09^{\mathrm{c}}$ \\
\hline
\end{tabular}

Results are presented as means \pm standard deviation. Results in the same column followed by different letters $(a, b, c, d)$ are significantly different by Tukey test $(\mathrm{p}<0.05)$. Sample identification: PU: freeze dried acerola pulp; PUG: freeze dried acerola pulp with $3 \%(\mathrm{w} / \mathrm{v})$ gum Arabic; PO: freeze dried acerola pomace; POG: freeze dried acerola pomace with $3 \%$ (w/v) gum Arabic.

\subsection{Color Analyses}

Freeze dried acerola pulp and pomace with gum Arabic had higher $L^{*}$ values $(p<0.05)$ when compared to corresponding samples without it (Table 3). This is a consequence of white colored gum Arabic that when mixed to food extracts produces lighter powders with higher luminosity (Khazaei, Jafari, Ghorbani, \& Kakhki, 2014). All samples showed positive values for $a^{*}$ and $b^{*}$ (Table 3 ) which indicate predominance of red/blue colors, respectively, that are typical of anthocyanin pigments.

Table 3. Color parameters ( $\mathrm{L}^{*}, \mathrm{a}^{*}$ and $\mathrm{b}^{*}$ ) of freeze dried acerola pulp (PU, PUG) and pomace (PO, POG) with and without gum Arabic.

\begin{tabular}{lllll}
\hline & PU & PUG & PO & POG \\
\hline $\mathrm{L}^{*}$ & $47.96 \pm 0.03^{\mathrm{d}}$ & $50.09 \pm 0.15^{\mathrm{c}}$ & $53.33 \pm 0.08^{\mathrm{b}}$ & $54.05 \pm 0.02^{\mathrm{a}}$ \\
$\mathrm{a}^{*}$ & $10.47 \pm 0.02^{\mathrm{b}}$ & $11.49 \pm 0.03^{\mathrm{a}}$ & $6.39 \pm 0.06^{\mathrm{c}}$ & $6.21 \pm 0.02^{\mathrm{d}}$ \\
$\mathrm{b}^{*}$ & $4.88 \pm 0.02^{\mathrm{d}}$ & $5.52 \pm 0.05^{\mathrm{c}}$ & $8.58 \pm 0.03^{\mathrm{a}}$ & $8.09 \pm 0.06^{\mathrm{b}}$ \\
\hline
\end{tabular}

Results are presented as means \pm standard deviation. Results in the same line followed by 


\section{Macrothink}

different letters $(a, b, c, d)$ are significantly different by Tukey test $(p<0.05)$. Legend: $L^{*}$ : brightness/darkness (0:black and 100: white), $\mathrm{a}^{*}$ : green $\left(-\mathrm{a}^{*}\right) /$ red $\left(+\mathrm{a}^{*}\right)$ coordinates; $\mathrm{b}^{*}$ : blue $\left(-b^{*}\right)$ yellow $\left(+b^{*}\right)$ coordinates. Sample identification: PU: freeze dried acerola pulp; PUG: freeze dried acerola pulp with 3\% (w/v) gum Arabic; PO: freeze dried acerola pomace; POG: freeze dried acerola pomace with $3 \%(\mathrm{w} / \mathrm{v})$ gum Arabic.

\subsection{Storage Stability of Ascorbic Acid, Total Phenolic Content, Anthocyanins and Antioxidant Activity At $4{ }^{\circ} \mathrm{CAnd} 25^{\circ} \mathrm{C}$}

\subsubsection{Ascorbic Acid}

Some ascorbic degradation $(2.0 \%-34.8 \%)$ was observed during the 120 -day storage for freeze dried acerola pulp with and without gum Arabic (Figure 4A). Major losses were observed after 15 days and steady values were obtained after this for both temperatures tested $\left(4{ }^{\circ} \mathrm{C}\right.$ and $\left.25^{\circ} \mathrm{C}\right)$. Gum Arabic was efficient in protecting ascorbic acid in acerola pulp from degradation and after 120 days, a remarkable retention of $88.9 \%$ e $72.2 \%$ was observed for dried pulp samples kept at $4{ }^{\circ} \mathrm{C}$ and $25{ }^{\circ} \mathrm{C}$, respectively. It is expected that freeze-drying causes lower phytochemical losses in comparison with other drying techniques, due to the low temperature and the absence of oxygen during drying. In fact, oxygen interactions are the main cause of ascorbic acid losses and consequent browning reactions. Similar results were reported by Agudelo et al. (2017), which found very low ascorbic acid reduction in freeze dried grapefruit.

Overall, the highest ascorbic acid retention was observed for samples with gum Arabic stored at refrigerated temperature $\left(4{ }^{\circ} \mathrm{C}\right)$. After 120 days of storage, these samples showed remarkable retention values of over 70\% (PUG4: 88.9\%; PU4: 72.8\%, respectively). On the hand, freeze dried acerola pulp without gum Arabic stored at $25{ }^{\circ} \mathrm{C}$ presented the lowest retention and after 120 days, only $65.2 \%$ of its initial AA concentration still remained. Therefore, both the storage temperature and addition of gum Arabic influenced the ascorbic acid retention of freeze dried acerola samples. Similarly, Castro-López et al. (2016) observed a gradual decrease in the ascorbic acid concentration of fruit juices during the first 8 days of storage and the best AA retention was observed at $4{ }^{\circ} \mathrm{C}$. In fact, it was already shown that higher temperature and oxygen exposure promote the oxidation and cleavage of covalent molecular bonds caused by enzymatic or non-enzymatic mechanisms, resulting in ascorbic acid losses (Chen \& Martynenko, 2017). 
(A)

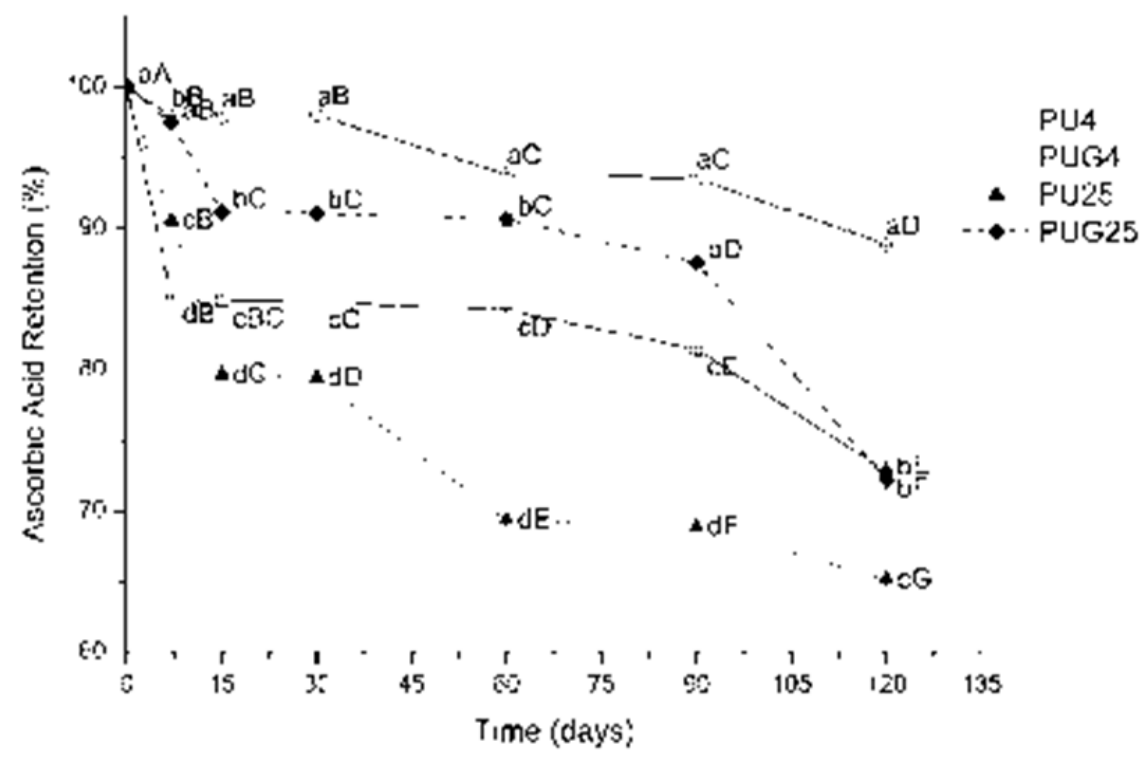

(B)

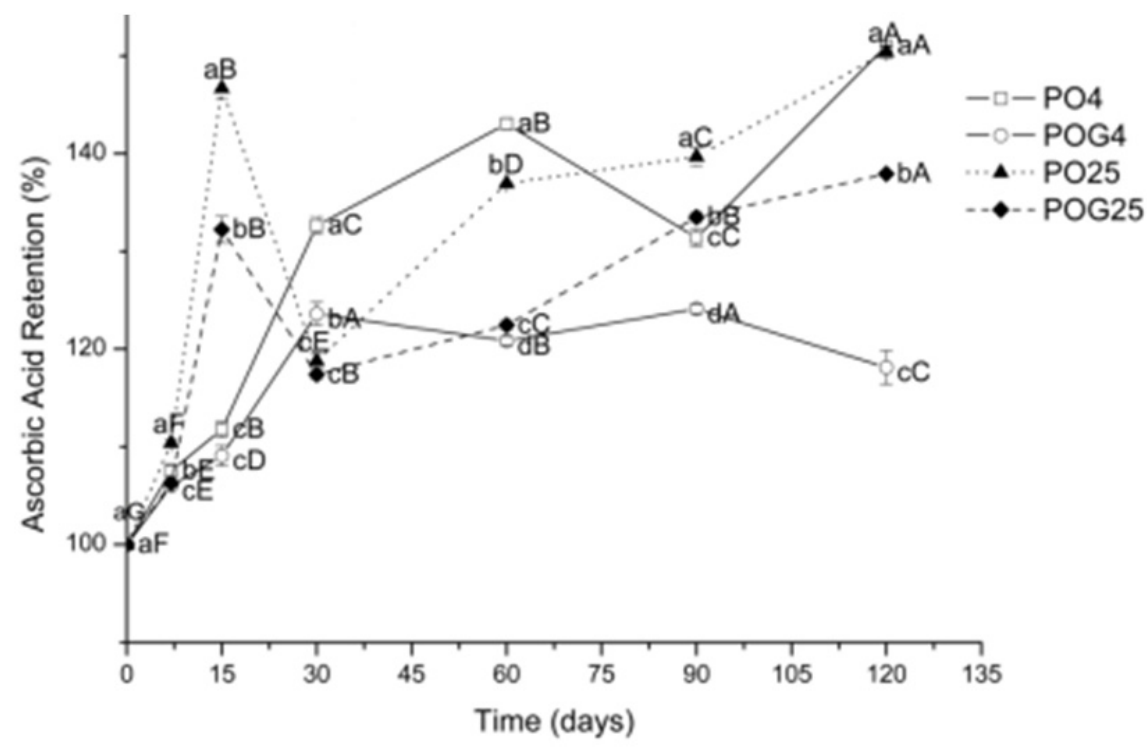

Figure 4. Ascorbic acid retention (\%) during 120-day storage of freeze dried acerola pulp (A) and pomace (B) with and without gum Arabic at $4{ }^{\circ} \mathrm{C}$ and $25^{\circ} \mathrm{C}$

Sample identification: A: PU4, PU25, freeze dried acerola pulp kept at $4{ }^{\circ} \mathrm{C}$ and $25{ }^{\circ} \mathrm{C}$, respectively; B: PUG4, PUG25, freeze dried acerola pulp with 3\% (w/v) gum Arabic kept at $4{ }^{\circ} \mathrm{C}$ and $25^{\circ} \mathrm{C}$, respectively; C: PO4, PO25, freeze dried acerola pomace kept at $4{ }^{\circ} \mathrm{C}$ and $25{ }^{\circ} \mathrm{C}$, respectively; D: POG4, POG25, freeze dried acerola pomace with $3 \%(\mathrm{w} / \mathrm{v})$ gum Arabic kept at $4{ }^{\circ} \mathrm{C}$ and $25{ }^{\circ} \mathrm{C}$, respectively. Different letters indicate significant difference by Tukey test $(\mathrm{p}<0.05)$ : $\mathrm{a}-\mathrm{d}$ : difference between experimental groups at each time point; $\mathrm{A}-\mathrm{G}$ : differences between each experimental group during the storage time (0-120 days). 


\section{Macrothink}

Interestingly, the ascorbic acid content of freeze dried acerola pomace increased during the storage at $4{ }^{\circ} \mathrm{C}$ and $25^{\circ} \mathrm{C}$ (Figure 4B). Previously, Shah et al. (2015) observed similar trend when studying the ascorbic acid behavior during storage of kinnow mandarin (Citrus reticulata cv. Blanco) fruits coated with carboxymethylcellulose (CMC) and gum guar containing silver nanoparticles. Since ascorbic acid is not generated or synthesized during storage, our hypothesis is that this increase may be attributed to disruption of acerola pomace cells, which increases its ascorbic acid extractability and the concentration detected by the assay (Aguilar, Garvín, Ibarz, \& Augusto, 2017).

\subsubsection{Total Phenolic Content (TPC)}

Figure 5A shows that the losses of phenolic compounds in freeze dried acerola pulp happened mainly during the first 30 days of storage. Between 30 days and 120 days of storage, a steady pattern was achieved and retentions around $60 \%$ were observed for all groups. After 120 days, freeze dried acerola pulp stored at refrigerated storage $\left(4^{\circ} \mathrm{C}\right)$ presented higher $(\mathrm{p}<0.05) \mathrm{TPC}$ retention (PU4 62.2\% and PUG4 63.0\%, when compared to the same samples stored at $25^{\circ} \mathrm{C}$ (PU25 60.7\% and PUG25 58.0\%), which indicates a significant temperature effect on TPC retention. On the other hand, the addition of gum Arabic had no clear influence on TPC retention. Similar behavior was observed by Oliveira, Lima, Clemente, Afonso, \& Costa (2015) when analyzing the TPC of freeze dried grugru palm (Acrocomia aculeate) with $8 \%$ $(\mathrm{w} / \mathrm{v})$ maltodextrin during 120 days of storage.

A different trend was observed for freeze dried acerola pomace (Figure 5B). An abrupt drop of TPC retention was observed after 7 days of storage for both temperatures and a steady plateau was established after this. Poor TPC retention was found both at $4{ }^{\circ} \mathrm{C}$ and $25{ }^{\circ} \mathrm{C}$, and after 120 days only $20 \%$ of the original TPC was detected in dried acerola pomace samples. Despite this, samples kept at lower temperature (PO4 23.6\%, POG4 23.2\%) presented higher TPC stability $(\mathrm{p}<0.05)$ when compared to $25{ }^{\circ} \mathrm{C}(\mathrm{PO} 2519.2 \%$, POG25 20.2\%) after 120 days of storage (For the sake of clarity, it is not shown in Figure 5). 
(A)

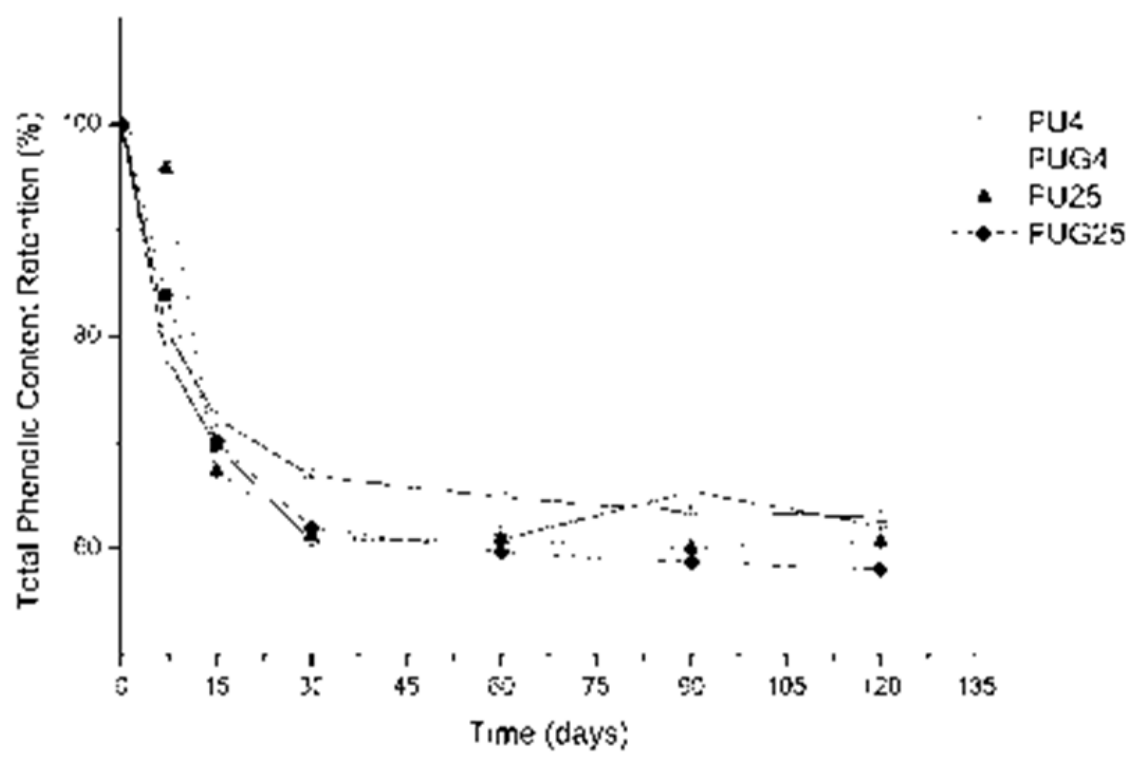

(B)

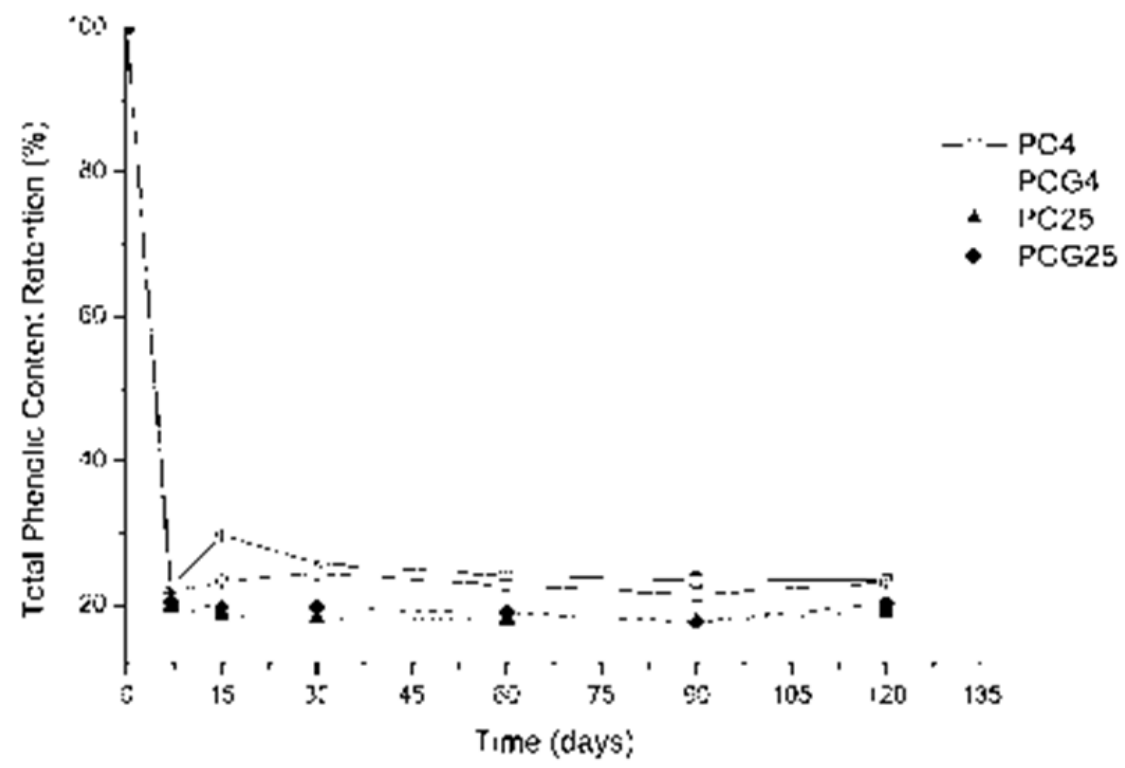

Figure 5. Total phenolic content retention (\%) during 120-day storage of freeze dried acerola pulp (A) and pomace (B) with and without gum Arabic at $4{ }^{\circ} \mathrm{C}$ and $25{ }^{\circ} \mathrm{C}$

Sample identification: A: PU4, PU25, freeze dried acerola pulp kept at $4{ }^{\circ} \mathrm{C}$ and $25{ }^{\circ} \mathrm{C}$, respectively; B: PUG4, PUG25, freeze dried acerola pulp with 3\% (w/v) gum Arabic kept at $4{ }^{\circ} \mathrm{C}$ and $25{ }^{\circ} \mathrm{C}$, respectively; C: PO4, PO25, freeze dried acerola pomace kept at $4{ }^{\circ} \mathrm{C}$ and $25{ }^{\circ} \mathrm{C}$, respectively; D: POG4, POG 25 , freeze dried acerola pomace with $3 \%(\mathrm{w} / \mathrm{v})$ gum Arabic kept at $4{ }^{\circ} \mathrm{C}$ and $25^{\circ} \mathrm{C}$, respectively. 


\section{Macrothink

\subsubsection{Total Monomeric Anthocyanins (ANC)}

Similarly to TPC, the anthocyanins retention in freeze dried acerola pulp kept at refrigerated storage was significantly higher than samples stored at room temperature (Figure 6A). Acerola pulp samples kept at $4{ }^{\circ} \mathrm{C}$ showed a remarkable ANC retention higher than $78 \%$ (78.7\% and $83.8 \%$ for PU4 and PUG4, respectively). Freeze dried acerola pomace samples followed similar trend with retention above $85 \%(87.1 \%$ and $93.5 \%$ for PO4 and POG4, respectively).

The milder process conditions used during freeze drying associated to lower storage temperature can cause less negative impact to thermally sensitive anthocyanins, but some degradation can still occurs due to oxygen. In fact, temperature is one of the major factors for anthocyanin stability (Sancho et al., 2015; Weber, Boch, \& Schieber, 2017). 
(A)

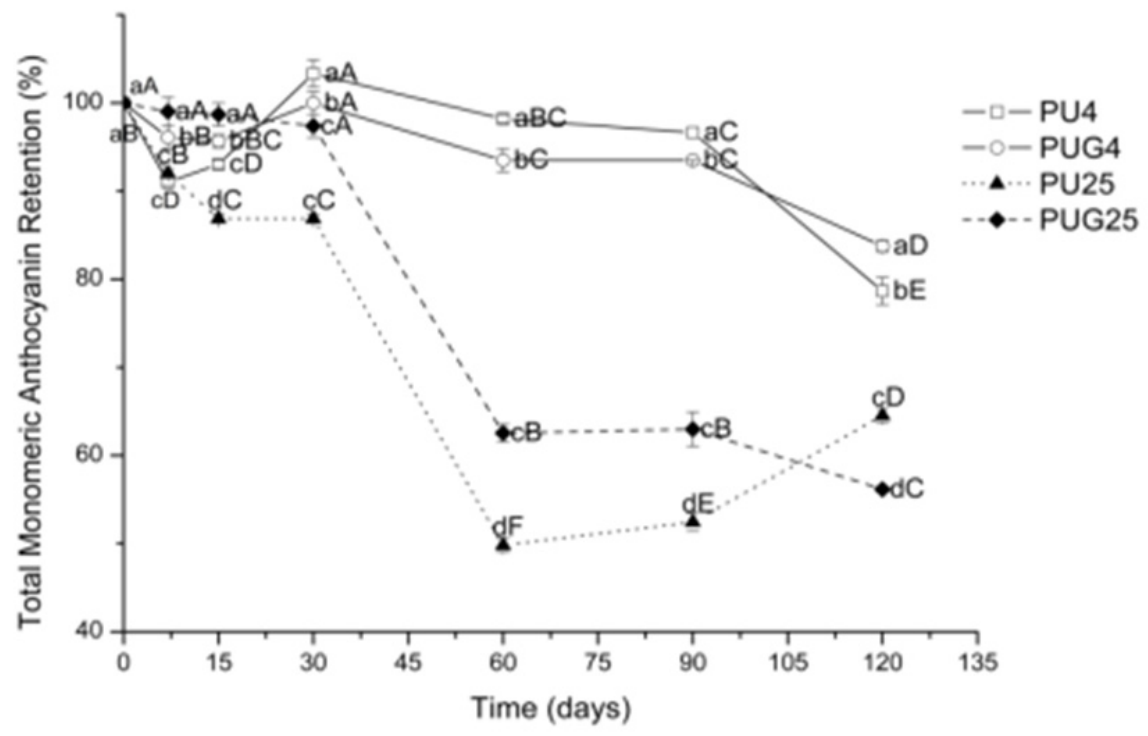

(B)

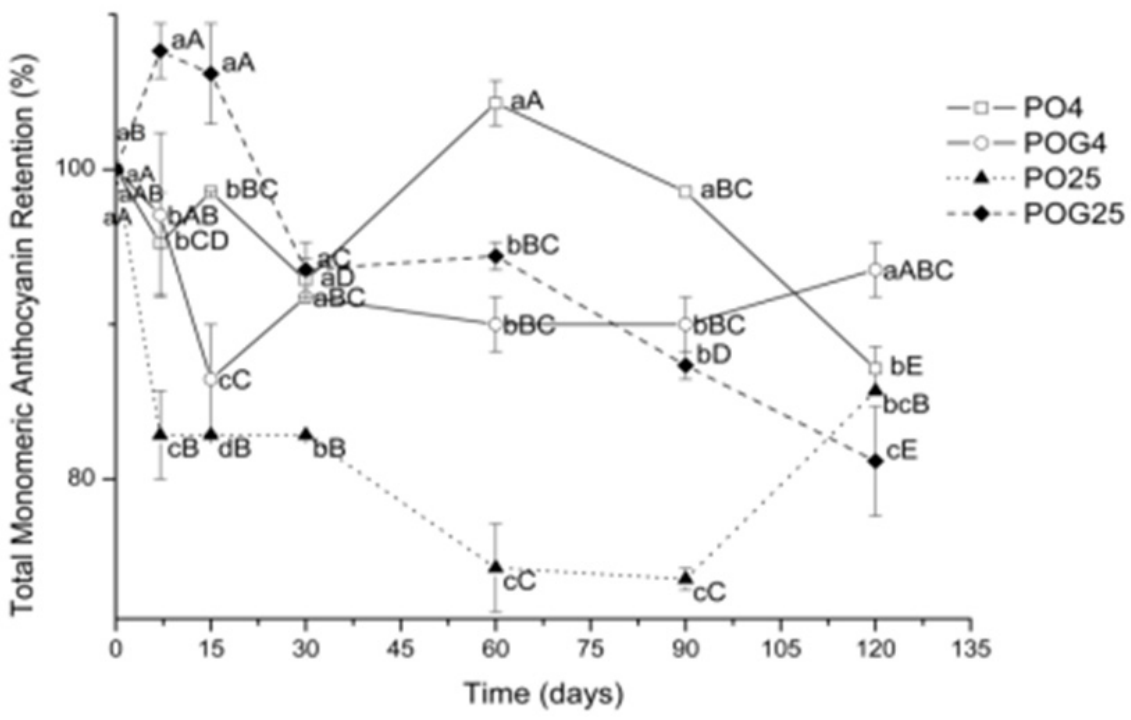

Figure 6. Total monomeric anthocyanin retention (\%) during 120-day storage of freeze dried acerola pulp (A) and pomace (B) with and without gum Arabic at $4{ }^{\circ} \mathrm{C}$ and $25{ }^{\circ} \mathrm{C}$

Sample identification: A: PU4, PU25, freeze dried acerola pulp kept at $4{ }^{\circ} \mathrm{C}$ and $25{ }^{\circ} \mathrm{C}$, respectively; B: PUG4, PUG25, freeze dried acerola pulp with 3\% (w/v) gum Arabic kept at $4{ }^{\circ} \mathrm{C}$ and $25{ }^{\circ} \mathrm{C}$, respectively; C: PO4, PO25, freeze dried acerola pomace kept at $4{ }^{\circ} \mathrm{C}$ and $25{ }^{\circ} \mathrm{C}$, respectively; D: POG4, POG25, freeze dried acerola pomace with $3 \%(\mathrm{w} / \mathrm{v})$ gum Arabic kept at $4{ }^{\circ} \mathrm{C}$ and $25{ }^{\circ} \mathrm{C}$, respectively. Different letters indicate significant difference by Tukey test $(\mathrm{p}<0.05)$ : a-d: difference between experimental groups at each time point; A-G: differences between each experimental group during the storage time (0-120 days). 


\section{Macrothink}

\subsubsection{Antioxidant Activity Measured by DPPH Assay}

The antioxidant activity of natural products is a multifaceted subject since it is influenced by multiple factors and compounds that interact in complex synergy. Several mechanisms are implicated such as metal quelating properties, radical scavenging activity and reducing power (Deng et al., 2014). Surprisingly, the antioxidant activity of freeze dried acerola pulp was kept high and constant during the entire storage period (Figure 7A). Similarly to what was observed for AA, the addition of gum Arabic influenced the antioxidant activity retention measured by DPPH method $(\mathrm{p}<0.05)$.

Acerola pomace samples presented a different pattern shown in Figure 7B. Overall, a slight drop in the antioxidant retention was observed after 15 days of storage, followed by increased values until a plateau was established after 120 days. A similar trend was observed in Citrus reticulata particles coated with different wall materials and silver nanoparticles (Shah et al., 2015).

Since ascorbic acid has an important role on antioxidant reactions, the high retention observed in this study (Figure 4B) might be implicated on the observed increase antioxidant activity of freeze dried acerola pomace (Mukherjee, Nema, Maity, \& Sarkar, 2013; Castro-López et al., 2016). 
(A)

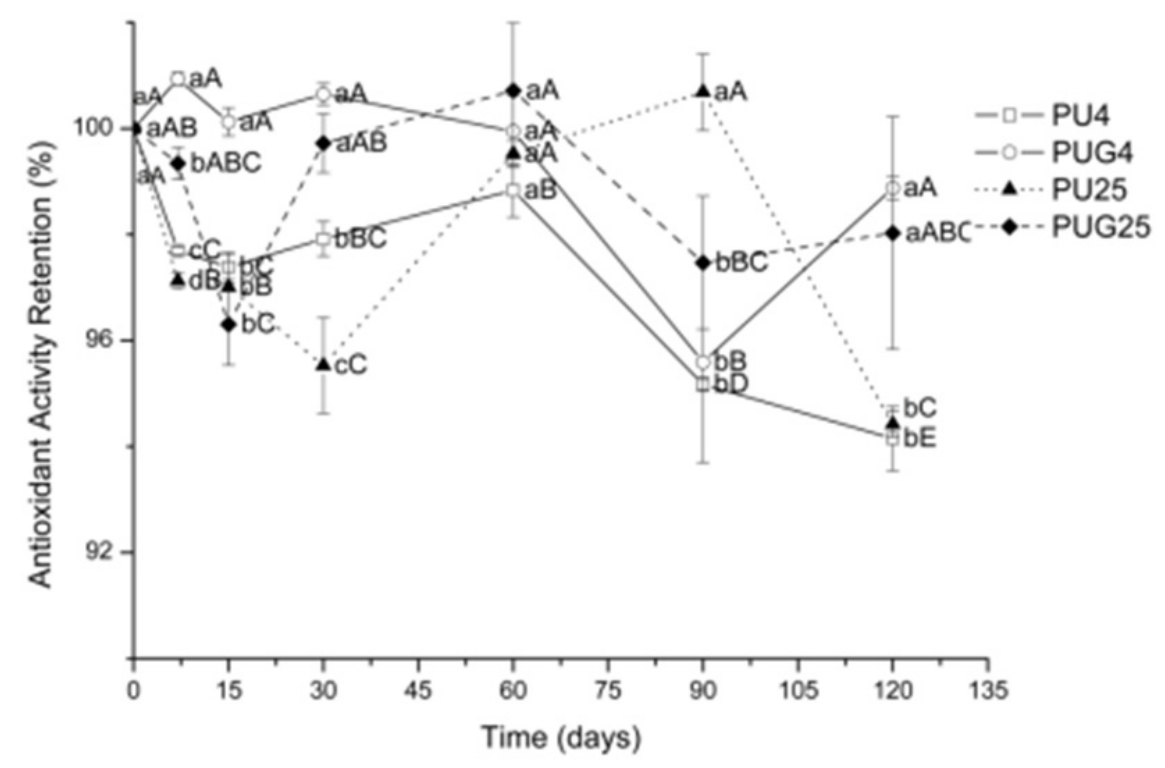

(B)

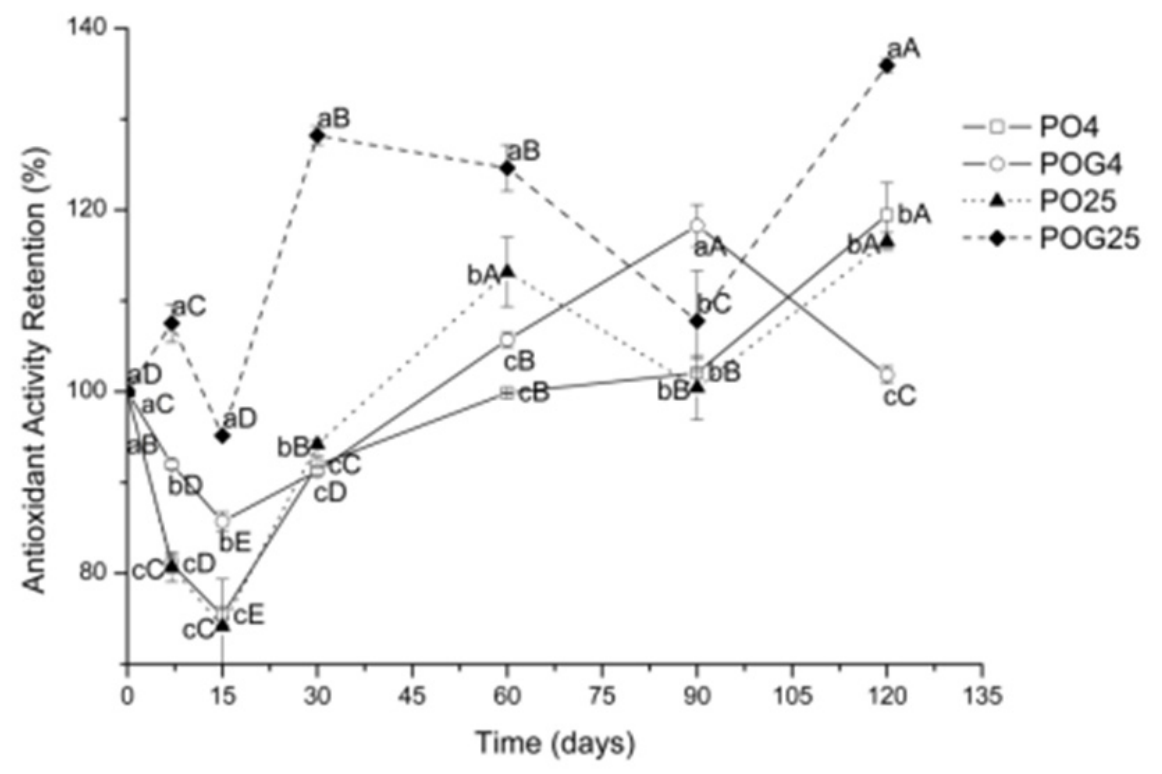

Figure 7. Antioxidant activity retention (\%) during 120-day storage of freeze dried acerola pulp (A) and pomace (B) with and without gum Arabic at $4{ }^{\circ} \mathrm{C}$ and $25{ }^{\circ} \mathrm{C}$

Sample identification: A: PU4, PU25, freeze dried acerola pulp kept at $4{ }^{\circ} \mathrm{C}$ and $25{ }^{\circ} \mathrm{C}$, respectively; B: PUG4, PUG25, freeze dried acerola pulp with 3\% (w/v) gum Arabic kept at $4{ }^{\circ} \mathrm{C}$ and $25{ }^{\circ} \mathrm{C}$, respectively; C: PO4, PO25, freeze dried acerola pomace kept at $4{ }^{\circ} \mathrm{C}$ and $25{ }^{\circ} \mathrm{C}$, respectively; D: POG4, POG25, freeze dried acerola pomace with $3 \%(\mathrm{w} / \mathrm{v})$ gum Arabic kept at $4{ }^{\circ} \mathrm{C}$ and $25{ }^{\circ} \mathrm{C}$, respectively. Different letters indicate significant difference by Tukey test $(\mathrm{p}<0.05)$ : a-d: difference between experimental groups at each time point; A-G: 
differences between each experimental group during the storage time (0-120 days).

\section{Conclusion}

This study showed that freeze dried acerola pulp and pomace with or without gum Arabic are non-hygroscopic, microbiologically stable food ingredients. The freeze dried acerola particles are highly porous, and constitute a mix of both amorphous and crystalline materials. It is possible to produce acerola powder products with high ascorbic acid retention during refrigerated storage, as well as optimal anthocyanin retention. The storage temperature is a major parameter for the preservation and stability of bioactive compounds. Lower temperature associated to the addition of gum Arabic allowed successful preservation of ascorbic acid and antioxidant activity in freeze dried acerola pulp and pomace.Overall, here we show that freeze dried acerola pulp and pomace may be successfully used as functional food ingredients in the food industry.

\section{References}

Agudelo, C., Barros, L., Santos-buelga, C., Martínez-navarrete, N., \& Ferreira, I. C. F. R. (2017). LWT - Food Science and Technology Phytochemical content and antioxidant activity of grapefruit (Star Ruby): A comparison between fresh freeze-dried fruits and different powder formulations. LWT - Food Science and Technology, 80, 106-112. https://doi.org/10.1016/j.lwt.2017.02.006

Aguilar, K., Garvín, A., Ibarz, A., \& Augusto, P. E. D. (2017). Ascorbic acid stability in fruit juices during thermosonication. Ultrasonics Sonochemistry, 37, 375-381. https://doi.org/10.1016/j.ultsonch.2017.01.029

Araujo-Díaz, S. B., Leyva-Porras, C., Aguirre-Manuelos, P., Álvarez-Salas, C., \& Saavedra-Leos, Z. (2017). Evaluation of the physical properties and conservation of the antioxidants content, employing inulin and maltodextrin in the spray drying of blueberry juice, 167, 317-325. https://doi.org/10.1016/j.carbpol.2017.03.065

Araújo, A. D. A., Coelho, R. M. D., Fontes, C. P. M. L., Silva, A. R. A., Da Costa, J. M. C., \& Rodrigues, S. (2015). Production and spouted bed drying of acerola juice containing oligosaccharides. Food and Bioproducts Processing, 94(August), 565-571. https://doi.org/10.1016/j.fbp.2014.08.005

Assis, S. A. de, Fernandes, F. P., Martins, A. B. G., \& Oliveira, O. M. M. de F. (2008). Acerola: importance, culture conditions, production and biochemical aspects, 63(2), 93-101. https://doi.org/10.1051/fruits

Aydin, E., \& Gocmen, D. (2015). The influences of drying method and metabisulfite pre-treatment onthe color, functional properties and phenolic acids contents and bioaccessibility of pumpkin flour. LWT - Food Science and Technology, 60(1), 385-392. https://doi.org/10.1016/j.lwt.2014.08.025

Azevêdo, J. C. S., Fujita, A., de Oliveira, E. L., Genovese, M. I., \& Correia, R. T. P. (2014). 


\section{Ml Macrothink}

Dried camu-camu (Myrciaria dubia H.B.K. McVaugh) industrial residue: A bioactive-rich Amazonian powder with functional attributes. Food Research International, 62, 934-940. https://doi.org/10.1016/j.foodres.2014.05.018

Cano-Chauca, M., Stringheta, P. C., Ramos, A. M., \& Cal-Vidal, J. (2005). Effect of the carriers on the microstructure of mango powder obtained by spray drying and its functional characterization. Innovative Food Science and Emerging Technologies, 6(4), 420-428. https://doi.org/10.1016/j.ifset.2005.05.003

Castro-López, C., Sánchez-Alejo, E. J., Saucedo-Pompa, S., Rojas, R., Aranda-Ruiz, J., \& Martínez-Avila, G. C. G. (2016). Fluctuations in phenolic content, ascorbic acid and total carotenoids and antioxidant activity of fruit beverages during storage. Heliyon, 2(9). https://doi.org/10.1016/j.heliyon.2016.e00152

Chen, Y., \& Martynenko, A. (2017). LWT - Food Science and Technology Storage stability of cranberry puree products processed with hydrothermodynamic (HTD) technology, 79. https://doi.org/10.1016/j.lwt.2016.10.060

Conceição, M. C., Fernandes, T. N., \& de Resende, J. V. (2016). Stability and microstructure of freeze-dried guava pulp (Psidium guajava L.) with added sucrose and pectin. Journal of Food Science and Technology, 53(6), 2654-2663. https://doi.org/10.1007/s13197-016-2237-5

Deng, Y., Yang, G., Yue, J., Qian, B., Liu, Z., Wang, D., ... Zhao, Y. (2014). Influences of ripening stages and extracting solvents on the polyphenolic compounds, antimicrobial and antioxidant activities of blueberry leaf extracts. Food Control, 38(1), 184-191. https://doi.org/10.1016/j.foodcont.2013.10.023

Duarte-Almeida J.M., Santos R. J., Genovese M. I., \& Lajolo F.M. (2006). Avaliação Da Atividade Antioxidante Utilizando Sistema B-Caroteno/Ácido Linoléico E Método De Seqüestro De Radicais Dpph•. Ciênc. Tecnol. Aliment., 26(2), 446-452. https://doi.org/10.1590/S0101-20612006000200031

Ezhilarasi, P. N., Indrani, D., Jena, B. S., \& Anandharamakrishnan, C. (2013). Freeze drying technique for microencapsulation of Garcinia fruit extract and its effect on bread quality. Journal of Food Engineering, 117(4), 513-520. https://doi.org/10.1016/j.jfoodeng.2013.01.009

Fujita, A., Borges, K., Correia, R., Franco, B. D. G. de M., \& Genovese, M. I. (2013). Impact of spouted bed drying on bioactive compounds, antimicrobial and antioxidant activities of commercial frozen pulp of camu-camu (Myrciaria dubia Mc. Vaugh). Food Research International, 54(1), 495-500. https://doi.org/10.1016/j.foodres.2013.07.025

Furlaneto, F. P. B., \& Nasser, M. D. (2015). Panorama da cultura da acerola no estado de São Paulo. Pesquisa E Tecnologia, 12(1), 1-6. https://doi.org/10.1017/CBO9781107415324.004

Giusti, M. \& Wrolstad, R. (2005). Characterization and measurement of anthocyanins by UVVisible spectroscopy. Current Protocols in Food Analytical Chemistry, (August 2016), 19-31. https://doi.org/10.1002/0471142913.faf0102s00 
GEA Niro Research Laboratory (2017). GEA Niro analytical methods. [Online] Available: http://www.niro.com/methods. (August 1, 2017).

Guillon, F., \& Champ, M. (2000). Structural and physical properties of dietary fibres, and consequences of processing on human physiology. Food Research International, 33(3-4), 233-245. https://doi.org/10.1016/S0963-9969(00)00038-7

Gurak, P. D., De Bona, G. S., Tessaro, I. C., \& Marczak, L. D. F. (2014). Jaboticaba pomace powder obtained as a co-product of juice extraction: A comparative study of powder obtained from peel and whole fruit. Food Research International, 62, 786-792. https://doi.org/10.1016/j.foodres.2014.04.042

Harnkarnsujarit, N., Kawai, K., Watanabe, M., \& Suzuki, T. (2016). Effects of freezing on microstructure and rehydration properties of freeze-dried soybean curd. Journal of Food Engineering, 184, 10-20. https://doi.org/10.1016/j.jfoodeng.2016.03.014

Jaeschke, D. P., Marczak, L. D. F., \& Mercali, G. D. (2016). Evaluation of non-thermal effects of electricity on ascorbic acid and carotenoid degradation in acerola pulp during $\begin{array}{lllll}\text { ohmic heating. } & \text { Food } & \text { 128-134. }\end{array}$ https://doi.org/10.1016/j.foodchem.2015.11.117

Jaya, S., \& Das, H. (2004). Effect of maltodextrin, glycerol monostearate and tricalcium phosphate on vacuum dried mango powder properties. Journal of Food Engineering, 63(2), 125-134. https://doi.org/10.1016/S0260-8774(03)00135-3

Karam, M. C., Petit, J., Zimmer, D., Baudelaire Djantou, E., \& Scher, J. (2016). Effects of drying and grinding in production of fruit and vegetable powders: A review. Journal of Food Engineering, 188, 32-49. https://doi.org/10.1016/j.jfoodeng.2016.05.001

Khazaei, K. M., Jafari, S. M., Ghorbani, M., \& Kakhki, A. H. (2014). Application of maltodextrin and gum Arabic in microencapsulation of saffron petal' $\mathrm{s}$ anthocyanins and evaluating their storage stability and color. Carbohydrate Polymers, 105, 57-62. https://doi.org/10.1016/j.carbpol.2014.01.042

Kuck, L. S., \& Noreña, C. P. Z. (2016). Microencapsulation of grape ( Vitis labrusca var . Bordo ) skin phenolic extract using gum Arabic, polydextrose, and partially hydrolyzed guar gum as encapsulating agents, 194, 569-576. https://doi.org/10.1016/j.foodchem.2015.08.066

López-Marcos, M. C., Bailina, C., Viuda-Martos, M., Pérez-Alvarez, J. A., \& Fernández-López, J. (2015). Properties of Dietary Fibers from Agroindustrial Coproducts as Source for Fiber-Enriched Foods. Food and Bioprocess Technology, 8(12), 2400-2408. https://doi.org/10.1007/s11947-015-1591-z

Mukherjee, P. K., Nema, N. K., Maity, N., \& Sarkar, B. K. (2013). Phytochemical and therapeutic potential of cucumber. Fitoterapia, 84(1), 227-236. https://doi.org/10.1016/j.fitote.2012.10.003

Nie, S. P., Wang, C., Cui, S. W., Wang, Q., Xie, M. Y., \& Phillips, G. O. (2013). A further amendment to the classical core structure of gum arabic (Acacia senegal). Food 
Hydrocolloids, 31(1), 42-48. https://doi.org/10.1016/j.foodhyd.2012.09.014

Nóbrega, E. M., Oliveira, E. L., Genovese, M. I., \& Correia, R. T. P. (2015). The impact of hot air drying on the physical-chemical characteristics, bioactive compounds and antioxidant activity of acerola (Malphigia emarginata) residue. Journal of Food Processing and Preservation, 39(2), 131-141. https://doi.org/10.1111/jfpp.12213

Nora, C. D., Müller, C. D. R., de Bona, G. S., Rios, A. de O., Hertz, P. F., Jablonski, A., ... Flôres, S. H. (2014). Effect of processing on the stability of bioactive compounds from red guava (Psidium cattleyanum Sabine) and guabiju (Myrcianthes pungens). Journal of Food Composition and Analysis, 34(1), 18-25. https://doi.org/10.1016/j.jfca.2014.01.006

Oliveira, D. M., Lima, C. G., Clemente, E., Afonso, M. R. A., \& Costa, J. M. C. Da. (2015). Stability of bioactive compounds and quality parameters of grugru palm powder (Acrocomia Aculeata) in different drying conditions. Journal of Food Quality, 38(2), 94-102. https://doi.org/10.1111/jfq.12126

Oliveira, R. G. De, Godoy, H. T., \& Prado, M. A. (2010). Otimização de metodologia colorimétrica para a determinação de ácido ascórbico em geleias de frutas. Ciência E Tecnologia de Alimentos, 30(1), 244-249. https://doi.org/10.1590/S0101-20612010000100036

Pasrija, D., Ezhilarasi, P. N., Indrani, D., \& Anandharamakrishnan, C. (2015). LWT - Food Science and Technology Microencapsulation of green tea polyphenols and its effect on incorporated bread quality. LWT - Food Science and Technology, 64(1), 289-296. https://doi.org/10.1016/j.lwt.2015.05.054

Paz, M., Gúllon, P., Barroso, M. F., Carvalho, A. P., Domingues, V. F., Gomes, A. M., ... Delerue-Matos, C. (2015). Brazilian fruit pulps as functional foods and additives: Evaluation of bioactive compounds. Food Chemistry, 172, 462-468. https://doi.org/10.1016/j.foodchem.2014.09.102

Risch, S. J., \& Reineccius, G. a. (1993). SYMPOSIUM Encapsulation and Controlled Release of Food Ingredients Science by Design, 1993-1996.

Sampaio, R. M., Neto, J. P. M., Perez, V. H., Marcos, S. K., Boizan, M. A., \& Da Silva, L. R. (2016). Mathematical Modeling of Drying Kinetics of Persimmon Fruits (Diospyros kaki cv. Fuyu). Journal of Food Processing and Preservation, O(Ibge 2012), n/a-n/a. https://doi.org/10.1111/jfpp.12789

Sancho, S. D. O., Da Silva, A. R. A., Dantas, A. N. D. S., Magalhaes, T. A., Lopes, G. S., Rodrigues, S., ... Silva, M. G. D. V. (2015). Characterization of the industrial residues of seven fruits and prospection of their potential application as food supplements. Journal of Chemistry, 2015. https://doi.org/10.1155/2015/264284

Shah, S. W. A., Jahangir, M., Qaisar, M., Khan, S. A., Mahmood, T., Saeed, M., ... Liaquat, M. (2015). Storage stability of kinnow fruit (Citrus reticulata) as affected by CMC and guar gum-based silver nanoparticle coatings. Molecules, 20(12), 22645-22661. 


\section{Macrothink}

https://doi.org/10.3390/molecules201219870

Silva, P. B., Duarte, C. R., \& Barrozo, M. A. S. (2016). Dehydration of acerola (Malpighia emarginata D.C.) residue in a new designed rotary dryer: Effect of process variables on main bioactive compounds. Food and Bioproducts Processing, 98, 62-70. https://doi.org/10.1016/j.fbp.2015.12.008

Soquetta, M. B., Stefanello, F. S., Huerta, K. D. M., Monteiro, S. S., Da Rosa, C. S., \& Terra, N. N. (2016). Characterization of physiochemical and microbiological properties, and bioactive compounds, of flour made from the skin and bagasse of kiwi fruit (Actinidia deliciosa). Food Chemistry, 199, 471-478. https://doi.org/10.1016/j.foodchem.2015.12.022

Souza, V. B., Thomazini, M., Balieiro, J. C. D. C., \& Fávaro-Trindade, C. S. (2015). Effect of spray drying on the physicochemical properties and color stability of the powdered pigment obtained from vinification byproducts of the Bordo grape (Vitis labrusca). Food and Bioproducts Processing, 93(November), 39-50. https://doi.org/10.1016/j.fbp.2013.11.001

Tonon, R. V., Brabet, C., \& Hubinger, M. D. (2010). Anthocyanin stability and antioxidant activity of spray-dried açai (Euterpe oleracea Mart.) juice produced with different carrier agents. Food Research International, 43(3), 907-914. https://doi.org/10.1016/j.foodres.2009.12.013

Tonon, R. V, Baroni, A. F., Brabet, C., Gibert, O., Pallet, D., \& Hubinger, M. D. (2009). Water sorption and glass transition temperature of spray dried açai (Euterpe oleracea Mart .) juice. Journal of Food Engineering, 94(3-4), 215-221. https://doi.org/10.1016/j.jfoodeng.2009.03.009

Weber, F., Boch, K., \& Schieber, A. (2017). Influence of copigmentation on the stability of spray dried anthocyanins from blackberry. LWT - Food Science and Technology, 75, 72-77. https://doi.org/10.1016/j.lwt.2016.08.042

\section{Copyright Disclaimer}

Copyright for this article is retained by the author(s), with first publication rights granted to the journal.

This is an open-access article distributed under the terms and conditions of the Creative Commons Attribution license (http://creativecommons.org/licenses/by/3.0/). 